Biogeosciences Discuss., 8, 2035-2056, 2011

www.biogeosciences-discuss.net/8/2035/2011/

doi:10.5194/bgd-8-2035-2011

(C) Author(s) 2011. CC Attribution 3.0 License.

\title{
Evidence for microbial dissolution of pyrite from the Lower Cambrian oolitic limestone, South China
}

\section{W. Liu and X.-L. Zhang}

State Key Laboratory of the Continental Dynamics, Early life Institute and Department of Geology, Northwest University, Xi'an 710069, China

Received: 1 February 2011 - Accepted: 11 February 2011 - Published: 2 March 2011

Correspondence to: X.-L. Zhang (xzhang69@nwu.edu.cn)

Published by Copernicus Publications on behalf of the European Geosciences Union.

Microbial pyrite dissolution in Cambrian sediments

W. Liu and X.-L. Zhang

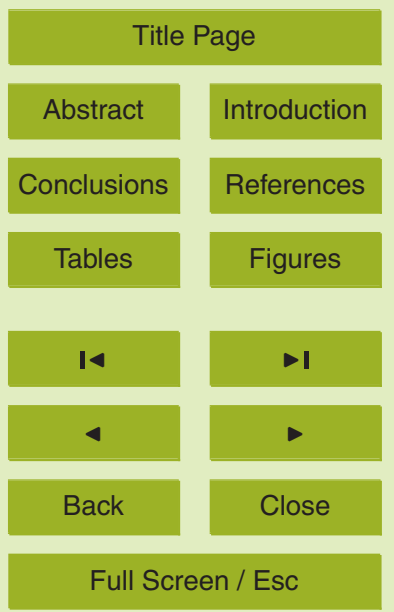

Printer-friendly Version

Interactive Discussion 


\section{Abstract}

The oxidative dissolution of the sulphide mineral pyrite $\left(\mathrm{FeS}_{2}\right)$ has been of significant interest since it affects global geochemical cycles, generates acid mine drainage, and is used in industrial metal extraction. Several different groups of prokaryotes are known to 5 catalyze the dissolution of pyrite and use the free energy generated from the oxidation, which may result in the dissolution of the mineral and the precipitation of the secondary ferric iron minerals either on the cell surface or is separated from the cells. However, straightforward evidence for such metabolic process in the ancient sediments is rare. Here we report pyrite crystals from the Lower Cambrian oolitic limestones that show indications of microbial erosion in various degrees. Erosion pits and tubular microtunnels with characteristic shapes and sizes in our samples are generally similar to those obtained from the laboratory studies on the oxidative dissolution of pyrite by ironoxidizing bacteria. Diagenetic examination demonstrates that the bioerosion predates the consolidation of the limestone. In addition, bacillus-sized and -shaped microfossils encrusted with iron oxides are present in our samples, which are very likely to be fossilized sheaths produced by iron-oxidizing bacteria. Our findings indicate that the microbial oxidative dissolution of pyrite existed in the Cambrian shallow marine carbonate sediments. Furthermore, we suggest that characteristic pitting patterns on the pyrite crystals from ancient sediments are an important clue to trace the evolution of life, in particular, the evolution of metabolism like microbial iron oxidation in the remote past on our planet, independent of biomarkers, isotopic signals and body fossils as well.

\section{Introduction}

The iron sulphide mineral pyrite is ubiquitous both in modern anoxic sediments and in sedimentary rocks. Its formation is usually linked to the activity of microbial sulphate reduction that requires the presence of organic matter as an electron donor (Konhauser,
BGD

8, 2035-2056, 2011

\section{Microbial pyrite dissolution in Cambrian sediments}

W. Liu and X.-L. Zhang

Title Page

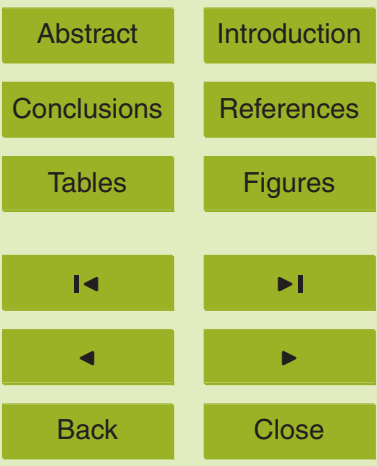

Full Screen / Esc

Printer-friendly Version

Interactive Discussion 
2007). The precipitation of the authigenic pyrite takes place very early within the sulphate reduction zone of the sediment column, where pore spaces are teeming with sulphate reducing bacteria. On the other hand, many iron- and sulphur-oxidizing microbes are also able to mediate the oxidative dissolution of pyrite for energy by oxidizing 5 the sulphur or the iron in pyrite (Hiltunen, et al., 1981; Mustin et al., 1992; Edwards et al., 1999; Frankel and Bazylinski, 2003; Madigan et al., 2003; Canfield et al., 2005; Posfai and Dunin-Borkowski, 2006; Kim and Gadd, 2008; Murphy and Strongin, 2009). On a par with the very ancient history of the microbial sulphate reduction that dates back to the early Archaean Era (Ohmoto et al., 1993; Shen et al., 2001), the geological 10 evidence of microbial dissolution of pyrite was also recently reported from 3.4 billionyear-old sediments (Wacey et al., 2011). Since numerous laboratory studies indicate that the pyrite oxidation under biotic conditions results in distinctive erosion marks on the mineral surface (Bennett and Tributsch, 1978; Hiltunen et al., 1981; Andrews, 1988; de Donato et al., 1991; Mustin et al., 1992, 1993; Aoki, 1999; Blight et al., 2000; Edwards et al., 2001; Rojas-Chapana and Tributsch, 2004; Ndlovu and Monhemius, 2004, 2005; Lu et al., 2006; Jiang et al., 2007) and such microbial imprints may be recordable in ancient sedimentary rocks, this allows us to trace the iron- and sulphur-oxidizing metabolism through Earth's history.

\section{Material and methods}

\subsection{Geological setting}

Our samples came from the bottom ooid grainstone of the Lower Cambrian Tianheban Formation at Wangjiaping Section in the Three-Gorge area, Hubei Province, South China (Fig. 1). Here, this rock unit is dominated by banded argillaceous limestones and bottomed by a $20 \mathrm{~cm}$ thick layer of oolitic limestone. The oolitic layer is occasionally interrupted by archaeocyathid bioherms. The sampled ooitic limestone preserved fine details of concentric ooids (dominant grain) and thus has experienced only

\section{BGD}

8, 2035-2056, 2011

\section{Microbial pyrite dissolution in Cambrian sediments}

W. Liu and X.-L. Zhang

Title Page

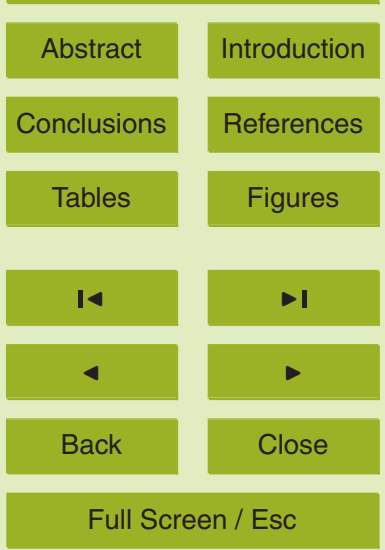

Printer-friendly Version

Interactive Discussion 
very-low-grade diagenetic alterations. Microfacies analysis indicates that the oolite was deposited in a sand shoal close to the platform margin (Liu and Zhang, 2010).

\subsection{Sample collection}

About 70 kilograms samples were collected from a single layer of Early Cambrian 5 oolitic limestones in field outcrops. 200 uncovered, polished petrographic thin sections $(2.5 \mathrm{~cm} \times 3.5 \mathrm{~cm}$ in size, $30 \mu \mathrm{m}$ in thickness) were prepared using standard thin section preparation techniques for light microscopic observation and imaging. The samples were also cut into slices of big slabs $(20 \times 20 \mathrm{~cm})$ to reveal the arrangement of ooid grains. Chemical etching was designed in room temperature $\left(25^{\circ} \mathrm{C}\right)$, using $5 \%$ acetic 10 acid. Before decalcification, samples were crushed into small fragments (about $2 \mathrm{~cm}$ in diameter). To eliminate dusts and other contaminations, only the fresh fragments were selected for further procedures and were rinsed several times using acetic acid and distilled water alternately. During decalcification, the acid liquor was replaced every $48 \mathrm{~h}$, and in the meantime insoluble residues were collected for picking up pyrite and 15 other interesting particles.

\subsection{Light and scanning microscopy}

Polished thin sections were examined and imaged under combined transmission and reflected lights using Nikon Eclipse LV100POL microscope. Thin sections were also etched with $3 \%$ hydrochloric acid for scanning electron microscopy (SEM) analy-

sis. Pyrite and other mineral particles picked up from the acid-resistant residues were mounted on sample stubs with conducting resin and coated with platinum. High-resolution SEM examinations of mineral particles were imaged with a FEI Quanta 400 SEM at the State Key Laboratory of Continental Dynamics, Northwest University, Xian China. The SEM was operated at $20 \mathrm{kV}$ in high vacuum mode, and images
BGD

8, 2035-2056, 2011

\section{Microbial pyrite dissolution in Cambrian sediments}

W. Liu and X.-L. Zhang

Title Page

Abstract

Introduction

Conclusions

Tables

References

Figures

14

$\rightarrow$

4

Back

Close

Printer-friendly Version

Interactive Discussion 
each SEM imaging, energy-dispersive X-ray spectra were acquired at interested points with an Oxford INCA 350 attached to the SEM.

\section{Results}

Thin section examination under light microscope shows abundance, arrangement and 5 morphology of pyrite crystals within the oolite. Scanning electron microscopy analyse reveals characteristic channels and pits within pyrite surfaces. Additionally, fossilized microbial structures were also observed in our samples.

\subsection{Pyrite under light microscopy}

Pyrite crystals are minute and relatively common in our samples. They occur as euhedral crystals that are mostly cubic and rectangular cuboid in morphology, ranging between 10-200 $\mu \mathrm{m}$ in crystal size (Fig. 2). The microcrystals are most commonly scattered within ooid grains, either evenly or concentrically, but less commonly coat the outer surface of ooids. Irregular aggregates of microcrystals are quite rare but they do occur in the matrix only. Spherical aggregates or framboids are completely absent in our samples albeit their frequent presence in ancient sediments. Examination of polished thin sections with reflective light microscopy demonstrates that crystals within the ooid grains are always smooth and have regular boundaries, while interstitial pyrite crystals between grains are usually imperfect, with irregular boundaries, absence of crystal corners and evident pits, which indicate considerable erosion. In rare cases, euhedral pyrite crystals may protrude out from the ooid grains. The exterior portion of the crystal soaring up from the ooid boundary has been extensively pitted, while the interior half remains intact (Fig. 2a-c).

\section{BGD}

8, 2035-2056, 2011

\section{Microbial pyrite dissolution in Cambrian sediments}

W. Liu and X.-L. Zhang

Title Page

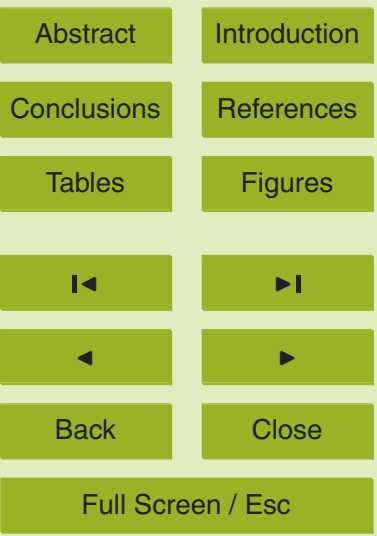

Printer-friendly Version

Interactive Discussion 


\subsection{Erosional features of pyrite under scanning microscopy}

Morphological analyses by Scanning Electron Microscope (SEM) indicate that around one-third of pyrite grains picked up from the acid-resistant residues, have erosion marks (Fig. 3). These pyrite crystals are pitted in differentiated degrees, resulting in numerous

5 pits and channels that penetrate into the mineral surface, varying 5-10 $\mu \mathrm{m}$ in diameter. In less eroded condition, crystal morphology can be well defined and isolated pits are observed on the crystal surfaces (see cubic forms in Fig. 3a). Figure $3 b$ shows an elongated pyrite crystal, probably rectangular cuboid in crystal morphology, with massive pits densely distributed on the crystal surface, forming an alveolate structure.

10 The pits penetrate into the crystal almost entirely in depth and develop into tubular forms. The tube wall has approximately the same thickness (around $0.3-0.5 \mu \mathrm{m}$ ) and possesses polygonal boundaries, more commonly pentagonal and hexagonal in cross section (Fig. $3 \mathrm{~b}$ and c). All the tubular pits are unbranched and have an uniform orientation perpendicular to a crystal faces. In the severest pitting condition, the bulk of 15 the pyrite crystal is dissolved, and thus it is unlikely to determine the crystal shape. As is shown in Fig. 3d, the remnants are parallel arranged micro-tubes (Fig. 3d) and bottoms of erosional pits due to collapse of tubular forms, with evident polygonal pattern (Fig. 3e). SEM examination of an unpolished thin section reveals an euhedral pyrite crystal that is moderately eroded (Fig. 3f). Massive erosion pits are present, which generally resemble those observed in the crystals from the acid-resistant residues.

\subsection{Fossilized iron-oxide sheaths}

Apart from pyrite crystals, we also obtained an irregularly shaped mineral particle from the acid-resistant residues of the Cambrian oolite, which was composed of abundant bacillus-sized and -shaped structures under the high magnification of SEM (Fig. 4).

\section{Microbial pyrite dissolution in Cambrian sediments}

W. Liu and X.-L. Zhang

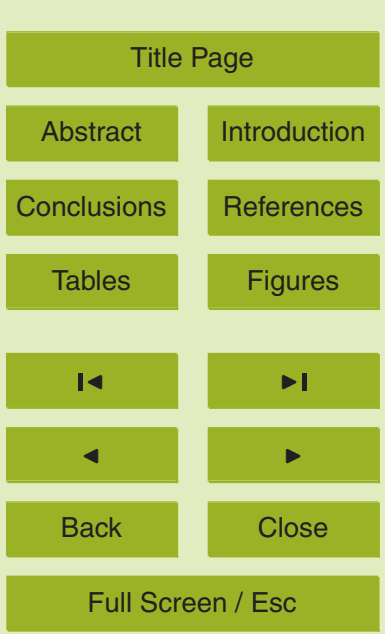

Printer-friendly Version

Interactive Discussion 


\section{Discussion}

\subsection{Biogenicity of dissolution pits}

It is generally accepted that diverse of iron- and sulphur-oxidizing microbes could mediate the oxidative dissolution of pyrite (Madigan et al., 2003; Posfai and Dunin-

5 Borkowski, 2006; Murphy and Strongin, 2009). Among the more studied microbial species, the activity of the iron-oxidizing bacteria Acidithiobacillus ferrooxidans and Leptospirillum ferrooxidans, and the iron-oxidizing archaeon Ferroplasma acidarmanus has been known to induce distinctive etching marks within the pyrite surface. Biological dissolution by the Acidithiobacillus ferrooxidans has been more extensively investigated and its leaching patterns were described varying slightly in individual studies (Bennett and Tributsch, 1978; Hiltunen et al., 1981; Andrews, 1988; de Donato et al., 1991; Mustin et al., 1992, 1993; Aoki, 1999; Blight et al., 2000; Edwards et al., 2001; Ndlovu and Monhemius, 2004, 2005; Lu et al., 2006; Jiang et al., 2007), probably due to minor difference in culture conditions for specific purpose, such as temperature of the solution, chemical composition and $\mathrm{pH}$ value of the reaction media, and duration of reaction. Shallow, approximately cell-sized and bacillus-shaped pits were observed in some studies (Hiltunen et al., 1981; Edwards et al., 2001), whereas elongate pits similar in shape to bacteria, but much larger than the bacterial cell dimensions were illustrated in other studies (Bennett and Tributsch, 1978; Mustin et al., 1992; Ndlovu and

Monhemius, 2004, 2005). Pits with polygonal boundaries were also found within pyrite surface leached by Acidithiobacillus ferrooxidans (Mustin et al., 1992, 1993). The dissolution pits by Leptospirillum ferrooxidans and Ferroplasma acidarmanus were much less studied than those by Acidithiobacillus ferrooxidans, each represented by a single publication. The aechaeon Ferroplasma acidarmanus was capable to produce elongate, well-developed dissolution pits (Edwards et al., 2001), generally similar to the larger pits by Acidithiobacillus ferrooxidans. The pyrite surface eroded by Leptospirillum ferrooxidans produced much larger pits, about 20-30 $\mu \mathrm{m}$ in diameter, commonly showing hexagonal patterns (Rojas-Chapana and Tributsch, 2004). In most of these

\section{Microbial pyrite dissolution in Cambrian sediments}

W. Liu and X.-L. Zhang

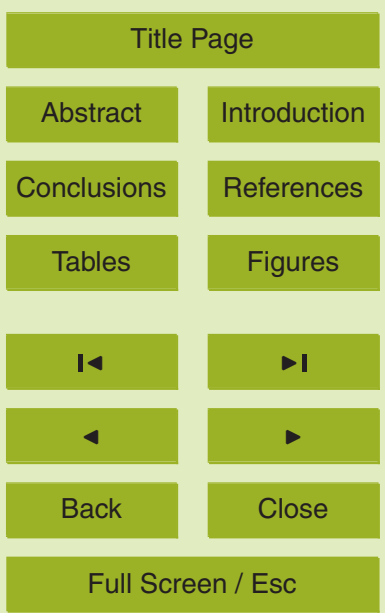

Printer-friendly Version

Interactive Discussion 
studies, dissolution pits were often found to have their main axis orientated in a welldefined direction, with polygonal pits present occasionally (e.g., Mustin et al., 1992, 1993; Rojas-Chapana and Tributsch, 2004).

Both discrete and massive dissolution pits were preserved in our samples from the 5 Cambrian rocks (Fig. 3). Such distribution pattern is not inconsistent with experimental results. In the early leaching stage, only shallow, discrete pits developed. The pit density and depth increased as the dissolution proceeded, and massive deep pits developed into a faveolate structure (Fig. $3 \mathrm{~b}$ and $\mathrm{c}$ ). The overall feature of a severe pitted crystal from the Cambrian samples (Fig. $3 b-e$ ) is strikingly similar to a pyrite particle 10 leached by Acidithiobacillus ferrooxidans for 43 days (Mustin et al., 1992, Fig. 8d). In both cases, pyrite was deeply pitted into honeycomb structures, and polygonal pits were well developed, but pits in the experimental study (Mustin et al., 1992) were relatively smaller and had a lower density. This minor difference could be as a result of longer time of exposure to bioleaching in geological samples. There were studies showing that average pit size and pitting density increased with reaction time (Edwards et al., 2001; Ndlovu and Monhemius, 2005). Much larger, hexagonal pits were observed on pyrite surfaces leached by Leptospirillum ferrooxidans for half year (RojasChapana and Tributsch, 2004).

Additionally, microbially mediated dissolution pits, hitherto known, appear to be specifically oriented, which were probably controlled by the surface properties of the pyrite crystal as was discussed by Ndlovu and Monhemius $(2004,2005)$. The pitforming mechanism is strongly influenced by the orientation of the oxidation individual planes susceptible to dissolution (Rojas-Chapana and Tributsch, 2004). A number of studies indicated that microbes seem to have a preferential attachment to sulphur enriched zones (Mustin et al., 1993; Edwards et al., 2001) such as dislocations (Andrews, 1988), the surface planes with high ratios of sulphur/iron atoms $(111 \mathrm{~B}, 100$, 110) (Ndlovu and Monhemius, 2005).

Abiotic chemical leaching of pyrite has been known to generate dissolution pits (Asta et al., 2008; Lefticariu et al., 2010). The leaching patterns were distinct from those

\section{BGD}

8, 2035-2056, 2011

\section{Microbial pyrite dissolution in Cambrian sediments}

W. Liu and X.-L. Zhang

Title Page

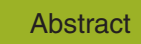

Introduction

Conclusions

Tables

References

Figures

14

$\rightarrow 1$

4

Back

Close
Printer-friendly Version

Interactive Discussion 
observed on bioleached samples. The erosion morphologies are mostly cracks and pits without any real systematic configuration or specific orientation (Pisapia et al., 2007). Pits are generally minute $(<0.5 \mu \mathrm{m}$ in maximum diameter), shallow and discrete (Edwards et al., 2001), which appear to be evenly distributed over the surface 5 with no apparent preference for any one type of site (Ndlovu and Monhemius, 2005). Importantly, the faveolate etching pattern (Fig. 3b) formed by deep, oriented, massive pits did not occur in the non-biological oxidation experiments. In contrast, the dissolution pits that develop on bio-oxidized pyrites are deep, polygonal (squares, lozenges, pentagons and hexagons) and oriented. The overall features of the dissolution pits 10 recorded in our geological material (Fig. 3) are generally in accordance with those of biologically induced pits that were observed in numerous experimental studies in distribution patterns, in pitting morphology and in well-defined orientation. They did not resemble any known chemical etching structures, and therefore, were probably a consequence of the microbial dissolution of the pyrite crystal.

\subsection{Pyrite oxidizing microbes}

Microbes that oxidize ferrous iron to ferric iron are generally thought to be the largest contributors to pyrite oxidation (Murphy and Strongin, 2009). Three distinct types of microbes have been known to oxidizing ferrous iron in different conditions (Madigan et al., 2003). Acidophiles, such as the bacteria Acidithiobacillus ferooxidans and Leptospirrillum ferrooxidans, as well as the archaeon Ferroplasma, oxidize iron in environments that have a very low $\mathrm{pH}$. Some microaerophiles (microorganisms living at the oxicanoxic interfaces), for example Gallionella ferruginea or Leptothrix ochracea, oxidize ferrous iron at circumneutral $\mathrm{pH}$. The third type of iron-oxidizing microbes are anaerobic photosynthetic bacteria such as Rhodopsuedomonas, which use ferrous iron to produce NADH for autotrophic carbon dioxide fixation. Currently, bioleaching patterns on pyrite surface have been revealed only in the acidophilic iron oxidizing microbes. They are similar to those preserved in our Cambrian samples. The interaction between pyrite and the other two types of iron oxidizing bacteria remain to be investigated.

\section{BGD}

8, 2035-2056, 2011

\section{Microbial pyrite dissolution in Cambrian sediments}

W. Liu and X.-L. Zhang

Title Page

Abstract

Introduction

Conclusions

Tables

References

Figures

14

$\rightarrow$

4

Back

Close

Full Screen / Esc

Printer-friendly Version

Interactive Discussion 
The bio-oxidation of pyrite by Acidithiobacillus ferooxidans often induces secondary mineral deposits (Edwards et al., 2001), which initially precipitated as ferric oxyhydroxide coating on the cell surfaces, aging into a number of iron minerals such as ferrihydrite and goethite (Frankel and Bazylinski, 2003). Therefore, the structures with iron oxides coating on cell surfaces probably represent fossilized iron oxide sheaths formed by microbes (Fig. 4). Although mineral formation by the bio-oxidation of pyrite may not have been demonstrated in every case, all iron oxidizing microbes should have this potential (Frankel and Bazylinski, 2003), for instance, the anaerobic neutrophilic ironoxidizing bacterium Acidovorax sp. precipitating amorphous iron phosphates (Miota 10 et al., 2009). Since the mineralized sheaths we found (Fig. 4) were preserved not directly associated with the dissolution pits, it was inconclusive to attribute pitting patterns on solid pyrite crystals to these microorganisms (they may grow by oxidation of soluble ferrous iron in pore water). However, the microfossils preserved as iron oxides again indicated that iron-oxidizing microbes were present in the Cambrian carbonate

\subsection{Timing and conditions of microbial etching}

Erosion imprints on pyrite have also commonly been found in thin sections without acid treatment (Figs. $2 a-c$ and $3 f$ ). Therefore, it can be readily rule out that the pyrite crystals were pitted during the etching process at laboratory. Thin section examination revealed that pyrite crystals within ooids were preserved intact, while those crossing the ooid margins were differentially leached in different portions, with exterior portions protruding out from the ooids pitted severely (Fig. 2a-c), which suggested that the dissolution took place within interstitial solution. The sampled limestone is ooid grainstones dominated by concentric ooids and was deposited in the platform-margin sand

shoals or open marine immediately adjacent, according to the Standard Microfacies Types (Flügel, 2004). Observation in field and on a polished rock slab demonstrated graded bedding in the sampled oolite (Fig. 6), suggesting that ooid sediments was once reworked by water currents. Diagenetic analysis recognized two generations of

\section{BGD}

8, 2035-2056, 2011

\section{Microbial pyrite dissolution in Cambrian sediments}

W. Liu and X.-L. Zhang

Title Page

Abstract

Introduction

Conclusions

Tables

References

Figures

14

$\rightarrow$

4

Back

Close

Full Screen / Esc

Printer-friendly Version

Interactive Discussion 
cements (Fig. 7a). The first generation is meniscus cements, with pendant, fibrous (bladed) calcite crystals oriented perpendicular to the grain edge, which is characteristic of eogenetic cements forming in the vadose zone. The second generation is granular mosaic cements, characterized by small pore-filling calcite crystals without 5 preferential orientations. Such interlocking crystals of clear calcite are believed to form during burial digenesis (mesogenetic cements). Figures $2 \mathrm{c}$ and $7 \mathrm{~b}$ demonstrate that early fibrous cements, hanging down from the edge of an ooid, penetrate into the dissolution pits on a pyrite crystal projecting from another ooid. Pyrite crystals were therefore pitted during earliest stages of burial, prior to cementation.

10 Combining microfacies and diagenetic data, we proposed that the ooid sediments were initially buried to the anoxic, sulphate reduction zone, below the oxygen-sulphide interface, where diagenetic pyrite formed. The sediments were then transported to the oxic, vadose zone, where pyrite was leached by interstitial microbial communities, followed by the early cementation. In terrestrial ecosystems, bio-oxidation of pyrite produces acid, resulting in low pH condition (Edwards et al., 1999; Posfai and DuninBorkowski, 2006). In marine sediments, any significant amount of acid would either diffuse in the bulk pore water or react with carbonate sediments. Therefore, it is reasonable to assume that pyrite of studied samples was leached in circumneutral conditions. Recently, many types of lithotrophic, oxygen-dependent Fe-oxidizing bacteria

\section{Conclusions}

Reconstructing the evolution of metabolism is a very difficult task. Theoretically, genomic and molecular genetic approaches are potentially important to elucidate the evolutionary history of life, especially some of the metabolic details. However, such approaches have severe limitations, and thus have little to tell us of the precise timing and/or exact sequence of events that resulted in the metabolic diversity life enjoys today (Nealson and Rye, 2005). There are also a number of geological or

\section{BGD}

8, 2035-2056, 2011

\section{Microbial pyrite dissolution in Cambrian sediments}

W. Liu and X.-L. Zhang

Title Page

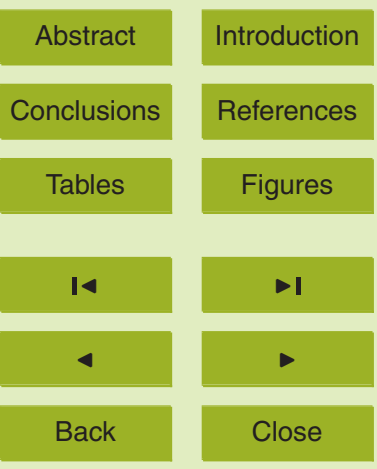

Full Screen / Esc

Printer-friendly Version

Interactive Discussion 
geochemical methods, all of which involve the analysis of the rock record for physical fossils, biomarkers, geochemical signature of inorganic sediments and biologically induced isotopic fractionation. As for the microbial oxidative dissolution of solid pyrite particles, it has been extensively demonstrated in the laboratory (Bennett and Trib5 utsch, 1978; Hiltunen et al., 1981; Andrews, 1988; de Donato et al., 1991; Mustin et al., 1992, 1993; Aoki, 1999; Blight et al., 2000; Edwards et al., 2001; Rojas-Chapana and Tributsch, 2004; Ndlovu and Monhemius, 2004, 2005; Lu et al., 2006; Jiang et al., 2007) and also in field rock outcrops in terrestrial habitats (Edwards et al., 1999). It may also attack pyrite of the hydrothermal metal sulphide deposits in deep seafloor, result10 ing in the imprints of bacterial cells (Verati et al., 1999; Edward et al., 2003). Microbial imprints on 3.4 billion-years-old detrital pyrite grains (Wacey et al., 2011), together with the presence of Banded Iron Formations (BIFs) in the early Achaean, suggested that microbes capable of metabolizing reduced iron and/or sulphur evolved very early in life history. To date, no direct evidence for microbial attacking solid pyrite has been 15 reported from younger sedimentary rocks, although the knowledge of microbial ironand sulphide-oxidation in recent marine sediments is accelerated.

Our findings, the characteristic leaching imprints on the surfaces of pyrite crystals and microbial fossils preserved as iron oxides from the Cambrian shallow marine carbonates, suggest that the bio-oxidation of pyrite may be widespread in ancient sediments. Such metabolic strategy may not only be restricted to deep marine hydrothermal habitats but also occur in shallow marine sediments. Furthermore, our work indicates that the pitting patterns stand intact in ancient rocks for hundreds of millions of years and are recognizable using standard geological techniques. Therefore, it can be used as a practical biosignature for investigating the evolution of lithotrophism such as the microbial oxidation of pyrite, possibly extending to other metal sulphide minerals, in ancient rocks.

Acknowledgements. The authors would like to thank the Natural Science Foundation of China (Grants: 40872004 and 40925005) and the "Sanqin Scholar" project of the Shaanxi Authority for financial support.

\section{BGD}

8, 2035-2056, 2011

\section{Microbial pyrite dissolution in Cambrian sediments}

W. Liu and X.-L. Zhang

Title Page

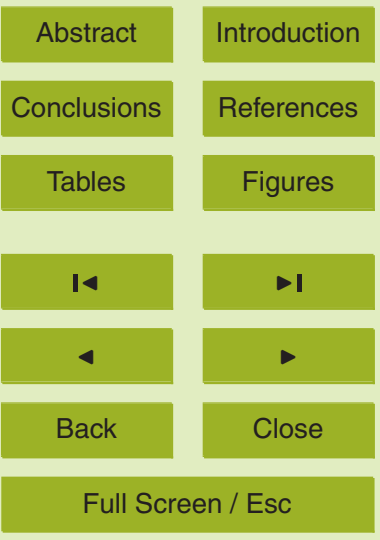

Printer-friendly Version

Interactive Discussion 


\section{References}

Andrews, F. G.: The selective adsorption of Thiobacilli to the dislocation sites on pyrite surfaces, Biotechnol. Bioeng., 31, 378-381, 1988.

Aoki, A: Acid bacterial leaching of pyrite single crystals, in: Biohydrometallurgy and the Environ5 ment Toward the Mining of the 21st Century, 9 (part 1), edited by: Amils, R. and Ballester, A., Process Metallurgy, Elsevier, Amsterdam, Netherlands, 119-125, 1999.

Asta, M. P., Cama, J., Soler, J. M., Arvidson, R. S., and Luttge, A.: Interferometric study of pyrite surface reactivity in acidic conditions, Am. Mineral., 93, 508-519, 2008.

Bennett, J. C. and Tributsch, H.: Bacterial leaching patterns on pyrite surfaces, J. Bacteriol., 134, 310-317, 1978.

Blight, K., Ralph, D. E., and Thurgate, S.: Pyrite surfaces after bio-leaching: a mechanism for bio-oxidation, Hydrometallurgy, 58, 227-237, 2000.

Canfield, D. E., Kristensen, E., and Thamdrup, B.: Aquatic Geomicrobiology, Elsevier, Amsterdam, Netherlands, 1-640, 2005.

15 de Donato, P., Mustin, C., Berthelin, J., and Marion, P.: An infrared investigation of pellicular phases observed on the pyrite by scanning electron microscopy, during its bacterial oxidation, C. R. Acad. Sci. Paris, t 321, serie II, 241-248, 1991.

Emerson, D., Fleming, E. J., and McBeth, J. M.: Iron-oxidizing bacteria - an environmental and genomic perspective, Annu. Rev. Microbiol., 64, 561-583, 2010.

20 Edwards, K. J., Goebel, B. M., Rodgers, T. M., Schrenk, M. O., Gihring, T. M., Cardona, M., Hu, B., McGuire, M. M., Hamers, R. J., Pace, N. R., and Banfield, J. F.: Geomicrobiology of pyrite $\left(\mathrm{FeS}_{2}\right)$ dissolution: case study at Iron Mountain, California, Geomicrobiol. J., 16, 155-179, 1999.

Edwards, K. J., Hu, B., Hamers, R. J., and Banfield, J. F.: A new look at microbial leaching patterns on sulfide minerals, FEMS Microbiol. Ecol., 34, 197-206, 2001.

Edward, K. J., McCollom, T. M., Konishi, H., and Buseck, P.: Seafloor bioalteration of sulfide minerals - results from in situ incubation studies, Geochim. Cosmochim. Ac., 67, 2843-2856, 2003.

Flügel, E.: Microfacies of Carbonate Rocks - Analysis, Interpretation and Application, Springer, Berlin, Germany, 1-976, 2004.

Frankel, R. B. and Bazylinski, D. A.: Biologically induced mineralization by bacteria, Rev. Mineral. Geochem., 54, 95-114, 2003.
BGD

8, 2035-2056, 2011

\section{Microbial pyrite dissolution in Cambrian sediments}

W. Liu and X.-L. Zhang

Title Page

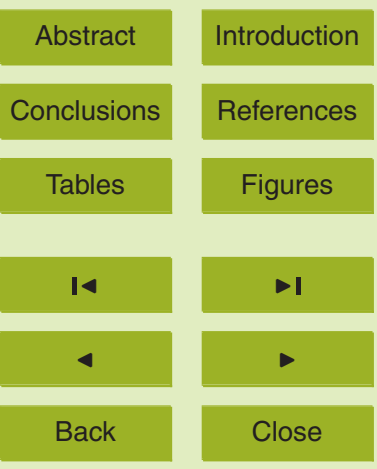

Full Screen / Esc

Printer-friendly Version

Interactive Discussion 
Hiltunen, P., Vuorinen, A., Rehtijärvi, P., and Tuovinen, O. H.: Bacterial yrite oxidation - release of iron and scanning electron microscopic observations, Hydrometallurgy, 7, 147-157, 1981.

Jiang L., Zhou, H.-Y., and Peng, X.-T.: Preliminary study on bio-oxidation of pyrite by Acidithiobacillus ferrooxidans, Acta Mineral. Sin., 27, 25-30, 2007 (in Chinese with English summary).

Kim, B. H. and Gadd, G. M.: Bacterial Physiology and Metabolism, Cambridge University Press, Cambridge, UK, 1-529, 2008.

Konhauser, K. O.: Introduction to Geomicrobiology, Blackwell, Oxford, UK, 1-425, 2007.

Lefticariu, L., Pratt, L. A., LaVerne, J. A., and Schimmelmann, A.: Anoxic pyrite oxidation by water radiolysis products - a potential source of biosustaining energy, Earth Planet. Sci. Lett., 292, 57-67, 2010..

Liu, W. and Zhang X.-L.: Analysis on the oolitic limestone microfacies and sedimentary environment of the Tianheban Formation, Lower Cambrian in the east part of the Three Gorges Area, Geol. Surv. Res., 33, 49-54, 2010 (in Chinese with English summary).

15 Lu, J.-J., Lu, X.-C., Wang, R.-C., Li, J., Zhu, C.-J., and Gao, J.-F.: Pyrite surface after Thiobacillus ferrooxidans leaching at $30^{\circ} \mathrm{C}$, Acta Geol. Sin., 80, 451-455, 2006.

Madigan, M. T., Martinko, J. M., and Parker, J. (Eds.): Brock Biology of Microorganisms, 10. Edn., Prentice Hall, Place, USA, 1-1019, 2003.

Miota, J., Benzerara, K., Morin, G., Kappler, A., Bernard, S., Obst, M., Férard, C., SkouriPanet, F., Guigner, J.-M., Posth, N., Galvez, M., Brown Jr., G. E., and Guyot, F.: Iron biomineralization by anaerobic neutrophilic iron-oxidizing bacteria, Geochim. Cosmochim. Ac., 73, 696-711, 2009.

Murphy, R. and Strongin, D. R.: Surface reactivity of pyrite and related sulfides, Surf. Sci. Rep., 64, 1-45, 2009.

Mustin, C., Berthelin, J., Marion, P., and de Donato, P.: Corrosion and electrochemical oxidation of a pyrite by Thiobacillus ferrooxidans, Appl. Environ. Microb., 58, 1175-1182, 1992.

Mustin, C., Berthelin, J., Marion, P., and de Donato, P.: Surface sulphur as promoting agent of pyrite leaching by Thiobacillus ferrooxidans, FEMS Microbiol. Rev., 11, 71, 1993.

Ndlovu, S. and Monhemius, A. J.: The role of orientation of crystal lattice on the development 30 of bacterial leaching patterns on pyrite single crystals, J. S. Afr. I. Min. Metall., 104, 573-578, 2004.

Ndlovu, S. and Monhemius, A. J.: The influence of crystal orientation on the bacterial dissolution of pyrite, Hydrometallurgy, 78, 187-197, 2005.

\section{BGD}

8, 2035-2056, 2011

\section{Microbial pyrite dissolution in Cambrian sediments}

W. Liu and X.-L. Zhang

Title Page

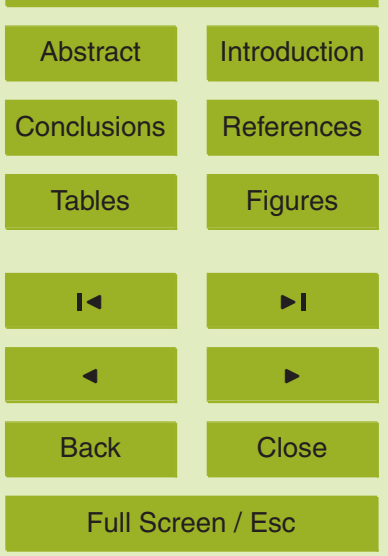

Printer-friendly Version

Interactive Discussion 
Nealson, K. H. and Rye, R.: Evolution of metabolism, Treatise Geochem., 8, 40-61, 2005.

Ohmoto, H., Kakegawa, T., and Lowe, D. R.: 3.4-Billion-year-old biogenic pyrites from Barberton, South Africa: sulfur isotope evidence, Science, 262, 555-557, 1993.

Pisapia, C., Chaussidon, M., Mustin, C., and Humbert, B.: O and S isotopic composition of dissolved and attached oxidation products of pyrite by Acidithiobacillus ferrooxidans - comparison with abiotic oxidations, Geochim. Cosmochim. Ac., 71, 2474-2490, 2007.

Posfai, M. and Dunin-Borkowski, R. E.: Sulfides in biosystems, Rev. Mineral. Geochem., 61, 679-741, 2006.

Rojas-Chapana, J. A. and Tributsch, H.: Interfacial activity and leaching patterns of Leptospirillus ferrooxidans on pyrite, FEMS Microbiol. Ecol., 47, 19-29, 2004.

Shen, Y.-A., Buick, R., and Canfield, D. E.; Isotopic evidence for microbial sulphate reduction in the Early Archaean era, Nature, 410, 77-80, 2001.

Verati, C., de Donato, P., Prieur D., and Lancelot, J.: Evidence of bacterial activity from micrometer-scale layer analyses of black-smoker sulfide structures (Pito Seamount Site, Easter Microplate), Chem. Geol., 158, 257-269, 1999.

Wacey, D., Saunders, M., Brasier, M. D., and Kilburn, M. R.: Earliest microbially mediated pyrite oxidation in 3.4 billion-year-old sediments, Earth Planet. Sci. Lett., 301, 393-402, 2011.

\section{BGD}

8, 2035-2056, 2011

\section{Microbial pyrite dissolution in Cambrian sediments}

W. Liu and X.-L. Zhang

Title Page

Abstract

Introduction

Conclusions

References

Tables

Figures

14

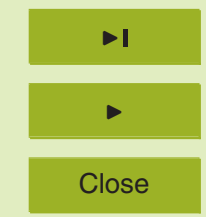

Back

Close

Full Screen / Esc

Printer-friendly Version

Interactive Discussion 
BGD

8, 2035-2056, 2011
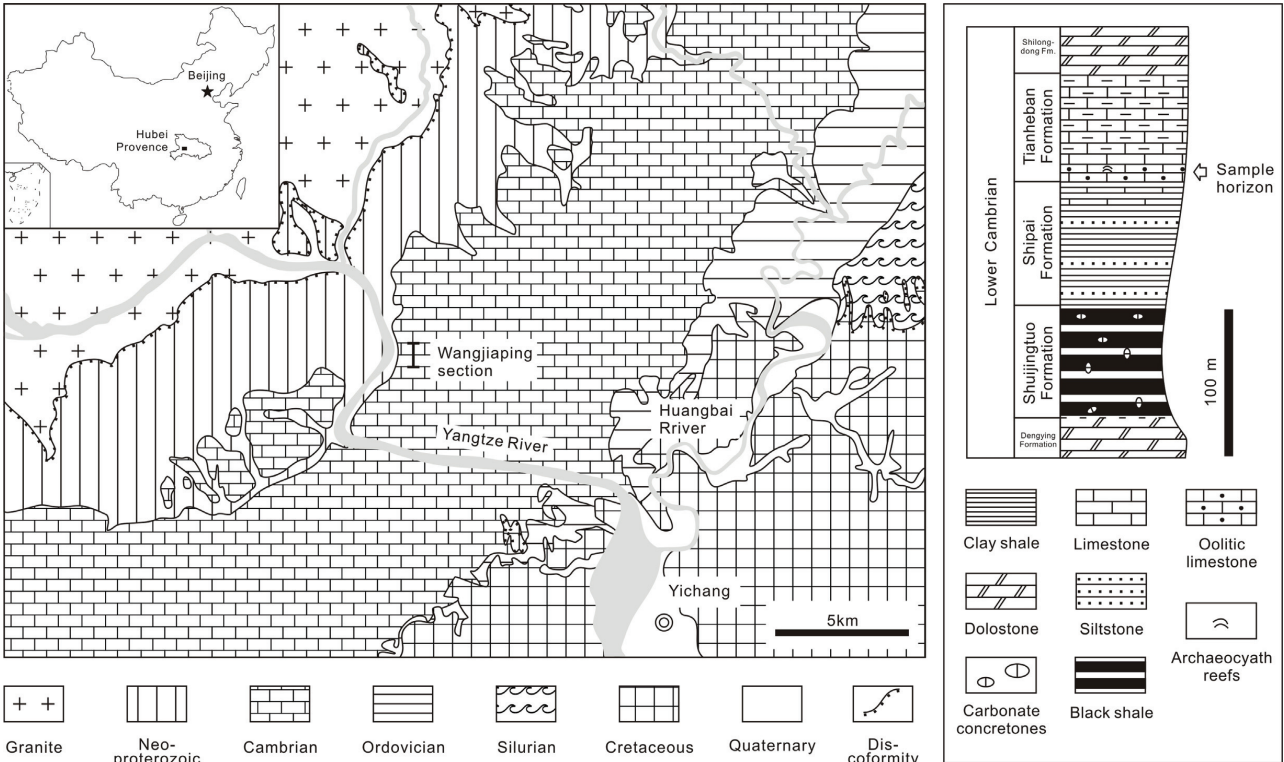

Fig. 1. Simplified geological map of the Three-Gorge area, Hubei Province, South China, showing the sampled locality and regional geology of the studied area (left), and Lower Cambrian stratigraphical column at the Wangjiaping section, indicating the horizon of samples (right).

\section{Microbial pyrite dissolution in \\ Cambrian sediments}

W. Liu and X.-L. Zhang

Title Page

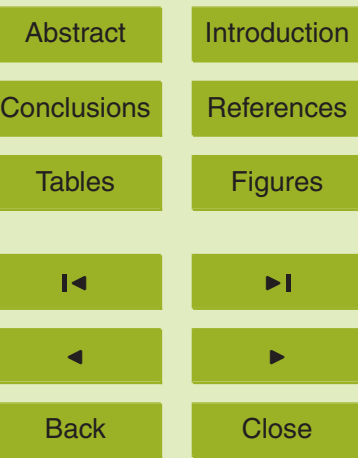

Full Screen / Esc

Printer-friendly Version

Interactive Discussion 

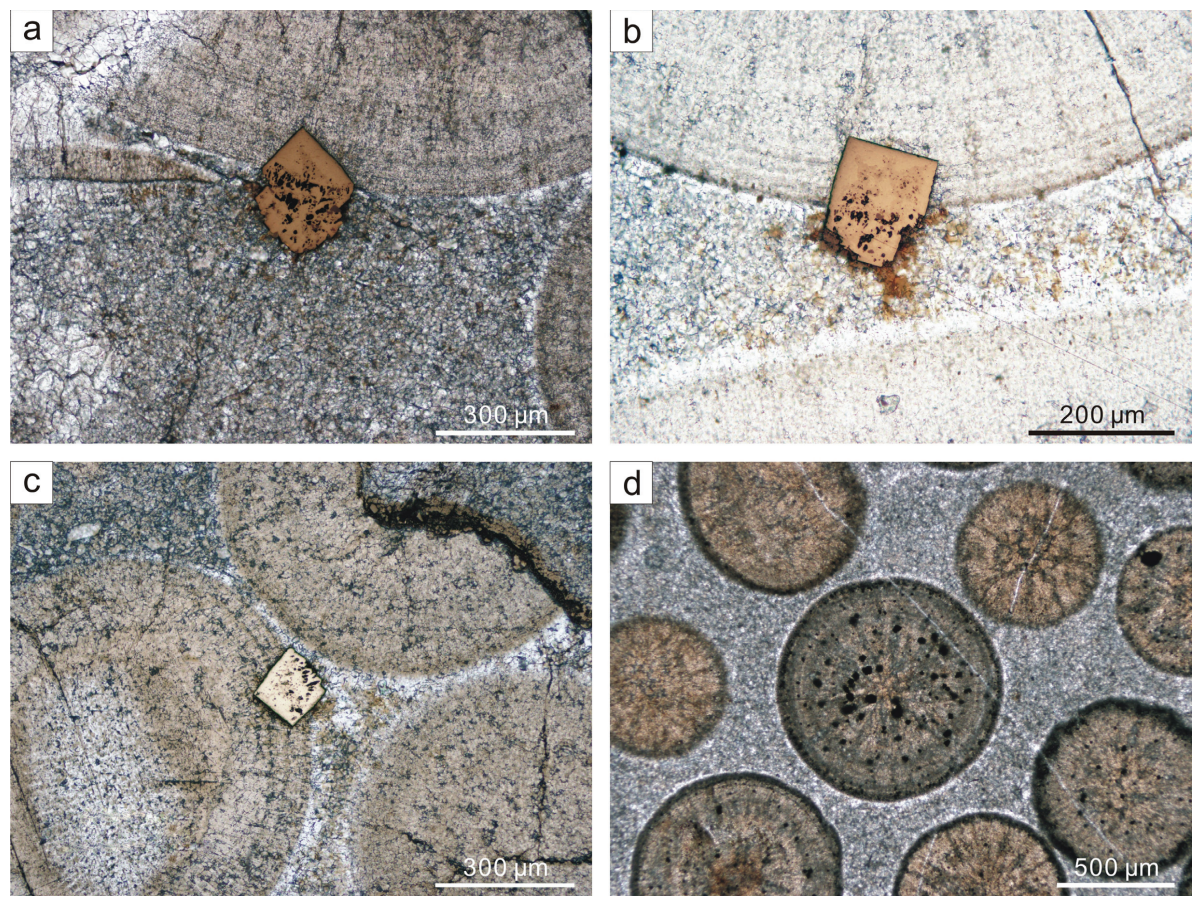

Fig. 2. Light microphotographs of petrographic thin sections showing features of pyrite crystals within the oolitic limestone. (a-c) Single pyrite crystals crossing the outer margin ooids, illumination using combined transmission and reflected lights. Note that portions protruding out from the ooids are considerably eroded while portions within ooids remain smooth and intact, and note also that early cements (bright) penetrate into the dissolution embayment. (d) Transmission light illumination, showing the distribution of pyrite (dark spots) within ooid.
BGD

8, 2035-2056, 2011

\section{Microbial pyrite dissolution in Cambrian sediments}

W. Liu and X.-L. Zhang

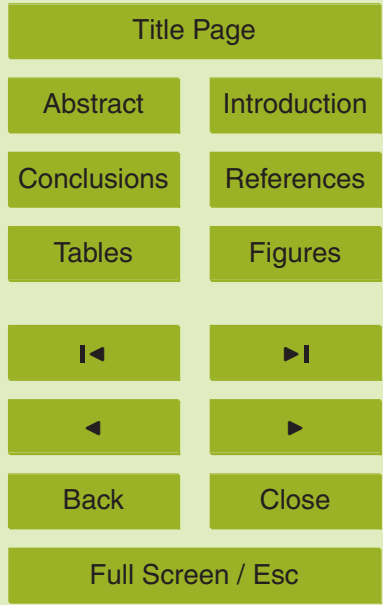

Printer-friendly Version

Interactive Discussion 

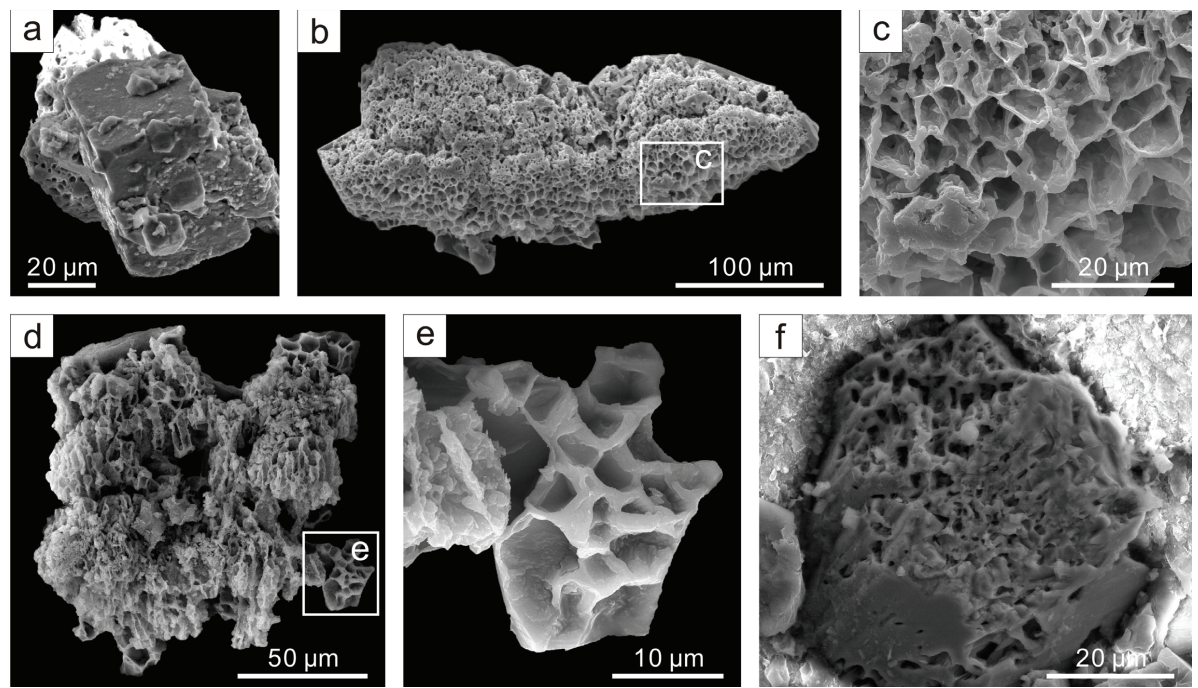

Fig. 3. Scanning electron microphotographs, showing microbially mediated discussion pits and channels within pyrite surface. Note that pyrite crystals were leached in varying degrees. (a) Cubic pyrite crystal with discrete pits. (b) Elongated cuboid pyrite crystal with massive, deep, oriented pits forming a honeycomb-like structure. (c) Enlargement of squared area in (b), showing polygonal boundaries of pits. (d) Severely eroded pyrite crystal, with deep, oriented pits developing into parallel tubular structures that are lying on the bottoms of pits due to collapse. (e) Enlargement of squared area in (d), showing pit bottoms and their polygonal boundaries. (f) A pyrite crystal in the thin section, with large number of dissolution pits.
BGD

8, 2035-2056, 2011

\section{Microbial pyrite dissolution in Cambrian sediments}

W. Liu and X.-L. Zhang

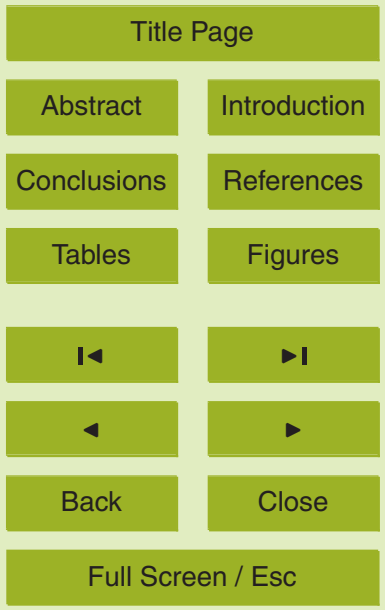

Printer-friendly Version

Interactive Discussion 


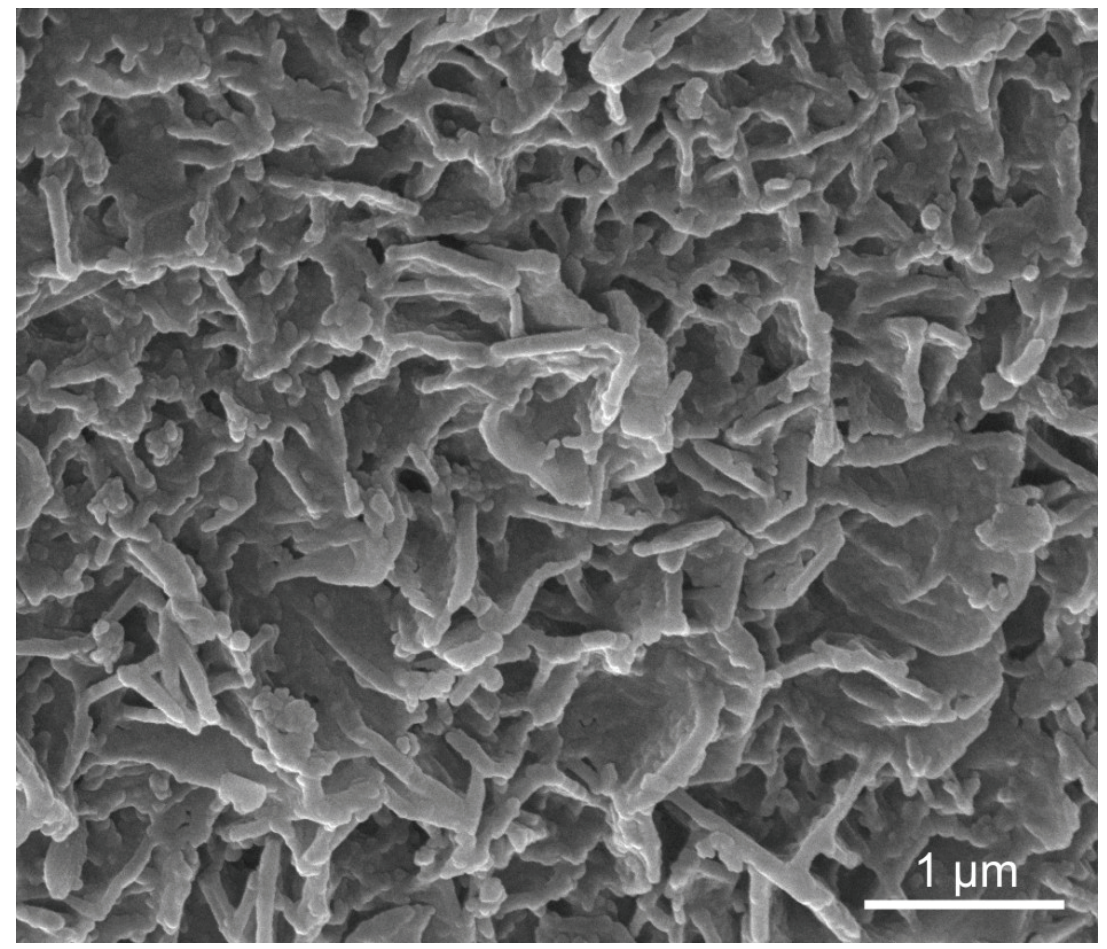

BGD

8, 2035-2056, 2011

\section{Microbial pyrite dissolution in \\ Cambrian sediments}

W. Liu and X.-L. Zhang

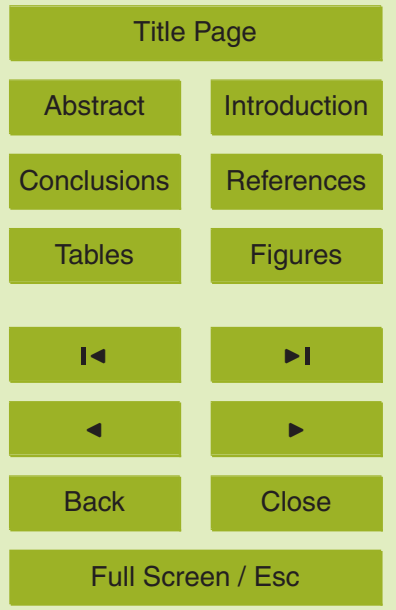

Fig. 4. Scanning electron microphotograph of a mineralized particle, showing bacillus-sized and -shaped structures.

Printer-friendly Version

Interactive Discussion 
BGD

8, 2035-2056, 2011

\section{Microbial pyrite dissolution in}

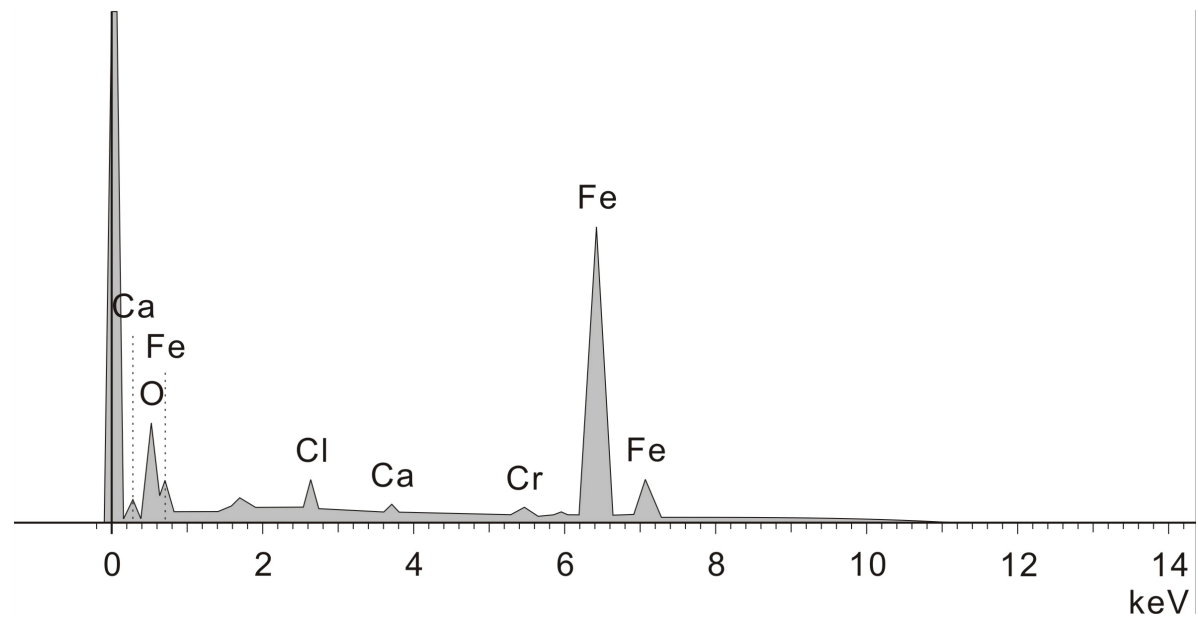

\section{Cambrian sediments}

W. Liu and X.-L. Zhang

Title Page

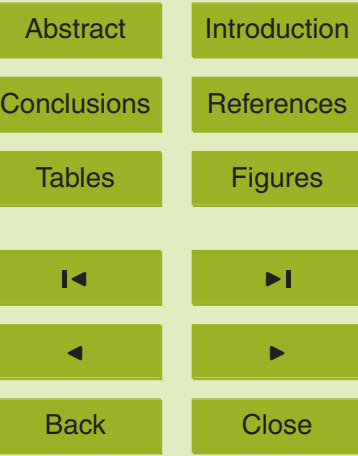

Full Screen / Esc

Printer-friendly Version

Interactive Discussion 


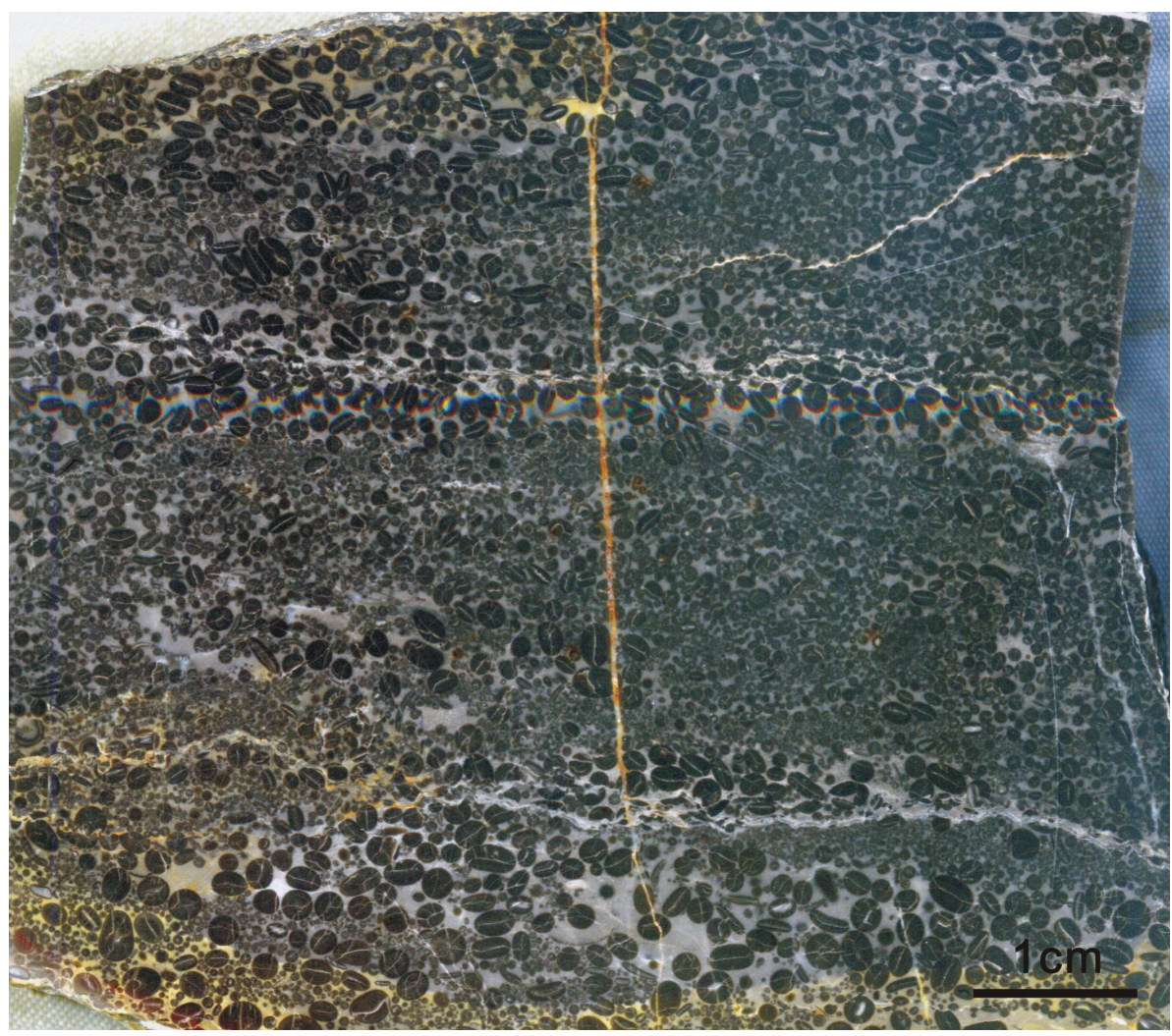

Fig. 6. Polished slab of the oolitic limestone, showing graded bedding.

\section{BGD}

8, 2035-2056, 2011

\section{Microbial pyrite dissolution in \\ Cambrian sediments}

W. Liu and X.-L. Zhang

Title Page

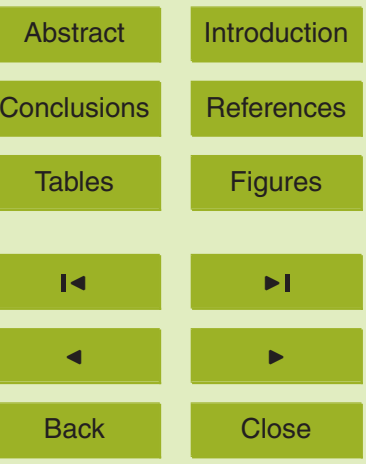

Full Screen / Esc

Printer-friendly Version

Interactive Discussion 

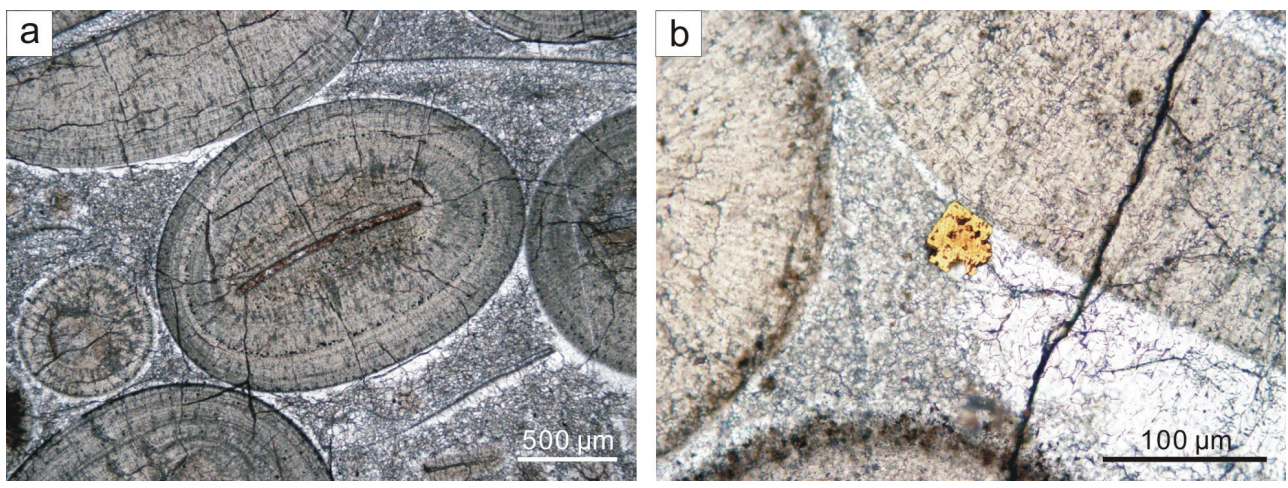

Fig. 7. Light microphotographs of petrographic thin sections showing diagenetic history of the oolitic limestone. (a) Transmission light illumination, showing two generations of cements: the early pendant, fibrous cements (bright) and the late granular, mosaic cements. (b) Combined transmission and reflected light illumination, showing that early fibrous cements extend into the pitted area of pyrite.
BGD

8, 2035-2056, 2011

\section{Microbial pyrite dissolution in \\ Cambrian sediments}

W. Liu and X.-L. Zhang

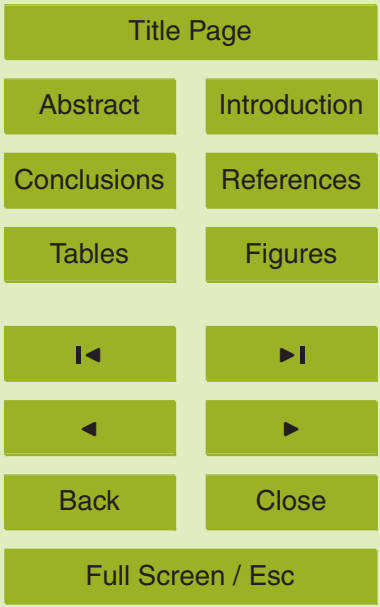

Printer-friendly Version

Interactive Discussion 